\title{
TERAPI BERBASIS VIDEO UNTUK MENINGKATKAN KETAJAMAN VISUAL PADA PENDERITA AMBLIOPIA
}

\author{
Silmi Chairan Andi \\ Universitas Mataram \\ Email: silmichairanandi@gmail.com
}

\begin{abstract}
Abstrak
Ambliopia yang berkembang pada tahap awal kehidupan menjadi penyebab utama gangguan penglihatan pada anak-anak. Ambliopia yang tidak segera diatasi dapat menyebabkan penurunan penglihatan permanen pada mata yang mengalami ambliopia dan menggangu fungsi penglihatan binocular. Lebih dari $70 \%$ pasien dapat memiliki penglihatan yang baik setelah mendapatkan terapi. Namun demikian, pengobatan terdahulu seperti oklusi mata dan terapi penalisasi menggunakan atropine seringkali memiliki tingkat kepatuhan rendah. Dibutuhkan terapi yang efektif, dengan tingkat kepatuhan yang dapat ditoleransi khususnya pada anak-anak serta memiliki waktu terapi lebih singkat dibandingkan dengan pengobatan konvensional. Tujuan penelitian ini yaitu untuk mengetahui pilihan terapi terbaru pada amblyopia. Metode penelitian yang digunakan dalam pemecahan permasalahan termasuk metode analisis. Sumber data penelitian ini berasal dari literatur yang diperoleh melalui internet berupa hasil penelitian dari jurnal internasional tahun 2011-2021 seperti Pubmed, Pubmed Central dan Elsevier. Hasil penelitian ini adalah terapi dengan berbasis I-BiT signifikan secara klinis meningkatkan ketajaman penglihatan baik pada kelompok yang menonton digital video disc (DVD) maupun pada kelompok yang bermain game. Kesimpulan dari penelitian ini adalah terapi berbasis video pada ambliopia memiliki manfaat bagi penderita ambliopia.
\end{abstract}

Kata kunci: ambliopia, video, terapi

\section{Abstract}

Amblyopia that develops in the early stages of life is a major cause of visual impairment in children. Amblyopia that is not treated immediately can cause permanent vision loss in the amblyopic eye and impair binocular vision. More than $70 \%$ of patients can have good vision after receiving therapy. However, previous treatments such as eye occlusion and penalizing therapy using atropine often have low adherence rates. Effective therapy is needed, with a level of adherence that can be tolerated, especially in children and has a shorter treatment time compared to conventional treatment. The purpose of this study was to determine the latest therapeutic options for amblyopia. The research methods used in problem solving include analytical methods. The source of this research 
data comes from literature obtained through the internet in the form of research results from international journals in 2011-2021 such as Pubmed, Pubmed Central and Elsevier. The result of this study is that therapy based on I-BiT is clinically significant in improving visual acuity both in the group watching digital video discs (DVD) and in the group playing games. The conclusion of this study is that video-based therapy in amblyopia has benefits for people with amblyopia.

Keywords: amblyopia, video, therapy

Diterima: 22-12-2021 Direvisi: 14-01-2022_Diterbitkan: 20-01-2022

\section{Pendahuluan}

Ambliopia merupakan kondisi turunnya visus unilateral atau bilateral walaupun dengan koreksi terbaik, tanpa kelainan struktur yang tampak pada mata atau lintasan visus (Ilyas and Yulianti, 2014). Ambliopia dianggap sebagai akibat gangguan perangsangan terhadap perkembangan fungsi visual pada tahap awal kehidupan sehingga sistem visual yang berkembang gagal mengirimkan gambar yang tajam ke korteks visual (Blair, Cibis and Gulani, 2021). Secara global, prevalensi ambliopia berkisar antara 0,2 \% - 6,2 \% dan sangat umum pada anak-anak (Mocanu and Horhat, 2020).

Ambliopia yang berkembang pada tahap awal kehidupan menjadi penyebab utama gangguan penglihatan pada anak-anak(Mocanu \& Horhat, 2020). Hal ini terjadi karena penggunaan mata yang tidak optimal selama perkembangan visual dari lahir hingga usia 7 tahun. Ambliopia yang tidak segera diatasi dapat menyebabkan penurunan penglihatan permanen pada mata yang mengalami ambliopia dan menggangu fungsi penglihatan binocular. Pengobatan sejak dini turut menentukan prognosis penderita ambliopia. Lebih dari $70 \%$ pasien dapat memiliki penglihatan yang baik setelah mendapatkan terapi (Blair et al., 2021).

Namun demikian, pengobatan terdahulu seperti oklusi mata dan terapi penalisasi menggunakan atropine seringkali memiliki tingkat kepatuhan rendah. Hal ini mungkin disebabkan oleh waktu penggunaan patch yang lama yaitu selama 2 sampai 14 jam per hari tergantung usia anak dan derajat ambliopianya dan dilanjutkan hingga didapatkan kondisi mata yang baik bahkan hingga berbulan-bulan (Riordan-Eva et al., 2013).

Kepatuhan terhadap oklusi mata seringkali buruk dengan hingga 50\% pasien tidak mematuhi dosis yang ditentukan, sehingga pengobatan tersebut mungkin tidak efektif di kalangan anak-anak. Terapi lain seperti penalisasi dengan pemberian atropin pada mata normal selama 2-7 hari per minggu akan mengganggu penglihatan dengan menimbulkan efek kabur pada mata (Ilyas \& Yulianti, 2014). Kedua terapi tersebut memiliki efek samping yaitu mata yang dioklusi atau diberikan atropin (mata normal) dapat menjadi ambliopia juga sehingga memerlukan pemantauan berkala. Hal ini dikarenakan terapi dengan oklusi atau penalisasi membuat kedua mata tidak bekerja secara harmonis. 
Oleh karena itu, dibutuhkan terapi yang efektif, dengan tingkat kepatuhan yang dapat ditoleransi khususnya pada anak-anak serta memiliki waktu terapi lebih singkat dibandingkan dengan pengobatan konvensional. Berdasarkan hal tersebut, penulis tertarik untuk membahas pengobatan alternatif lain pada mata ambliopia sehingga dapat meningkatkan prognosis.

\section{Metode Penelitian}

Metode penelitian yang digunakan dalam pemecahan permasalahan termasuk metode analisis. Sumber data penelitian ini berasal dari literatur yang diperoleh melalui internet berupa hasil penelitian dari jurnal internasional tahun 2011-2021 seperti Pubmed, Pubmed Central dan Elsevier.

\section{Hasil dan Pembahasan}

Ambliopia berasal dari bahasa yunani yaitu amblys (tumpul) dan ops (mata). Ambliopia diartikan sebagai keadaan turunnya visus unilateral atau bilateral walaupun dengan koreksi terbaik, tanpa adanya kelainan organik yang mendasari (Ilyas \& Yulianti, 2014). Ambliopia disebabkan oleh kurangnya ransangan untuk meningkatkan perkembangan penglihatan yang terjadi pada tahap awal kehidupan sehingga sistem visual yang berkembang gagal mengirimkan gambar yang tajam ke korteks visual (Blair et al., 2021). 
Ambliopia dibagi menjadi tiga berdasarkan penyebabnya, yaitu yang disebabkan oleh strabismus, kelainan refraksi dan deprivasi visual.

Gambar 1. Etiopatogenesis ambliopia

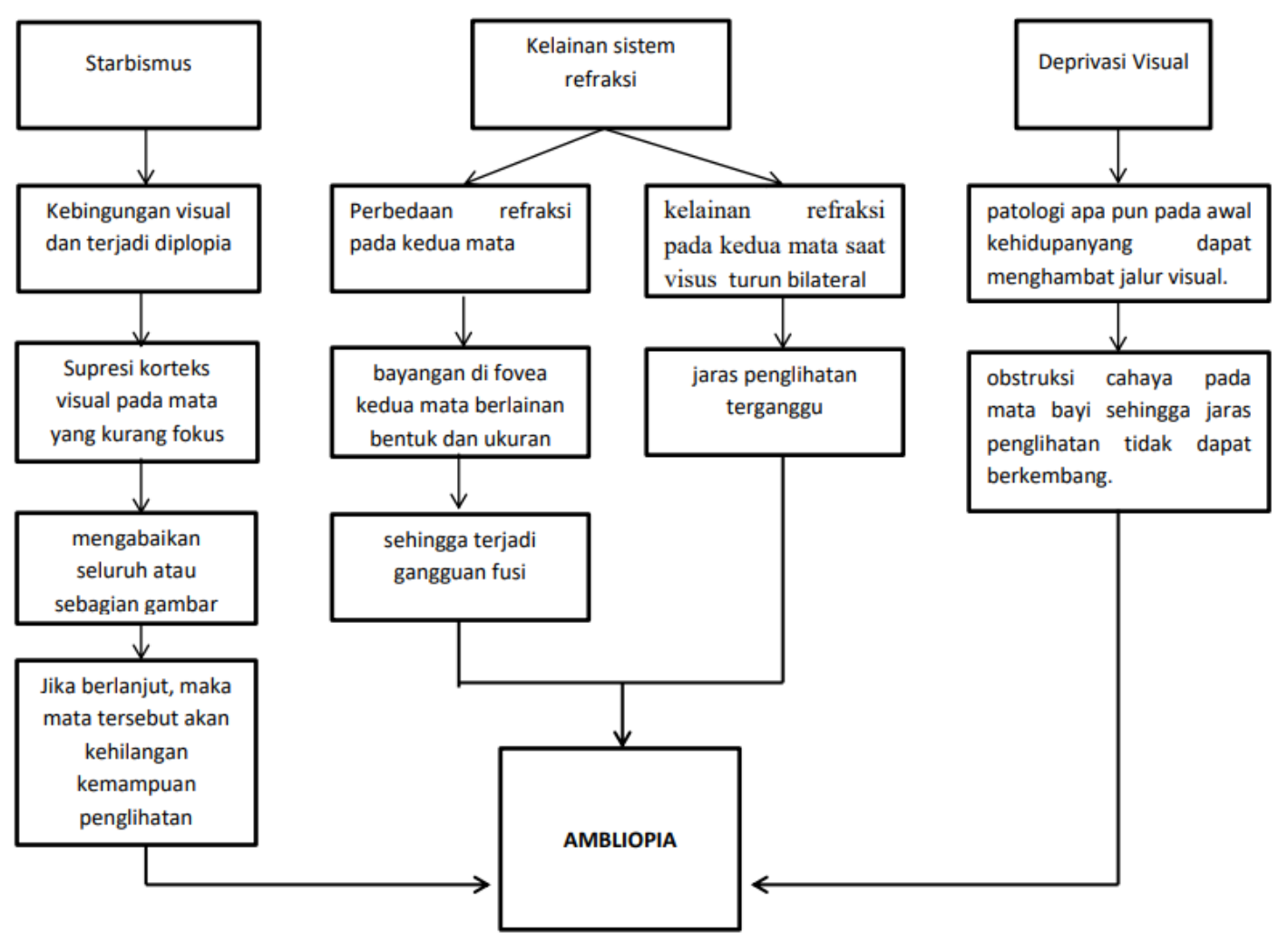

Terapi pada mata ambliopia didasarkan pada patogenesis yang mendasari. Pada tahap awal dilakukan suatu pengobatan untuk menyingkirkan faktor ambliopiagenik seperti dilakukan terapi oklusi pada kondisi strabismus dan dilakukan operasi untuk mensejajarkan aksis visualis. Membersihkan aksis visualnya seperti operasi katarak dan operasi ptosis. Faktor ambliopiagenik tidak lagi berpengaruh pada ambliopia setelah usia pasien lebih dari 7 tahun (Ilyas \& Yulianti, 2014).

Terapi pada mata ambliopia secara konvesional adalah oklusi mata dengan menggunakan patch atau jika tidak toleransi dapat dilakukan penalisasi dengan pemberian atropin pada mata normal. Terapi oklusi merupakan gold standard pada penanganan ambliopia. Namun demikian, kedua terapi ini memiliki beberapa kekurangan yaitu durasi terapi yang lama sehingga mempengaruhi tingkat kepatuhan. Penggunaan patch mata pada anak juga menggangu hubungan sosial anak dalam berinteraksi. Selain itu penggunaan atropine dalam jangka panjang dapat menimbulkan efek sistemik.

Saat ini beberapa penelitian terbaru menunjukkan terapi lain yang dapat diberikan pada pasien ambliopia yaitu terapi berbasis video. Interactive Binocular Treatment (IBiT) merupakan perangkat keras yang terdiri dari komputer desktop dengan dua 
monitor yaitu satu untuk dokter atau pemantau dan satu untuk pasien. Pasien akan menggunakan kacamata rana 3D dan pemancar infra merah dengan monitor pasien berupa monitor 3D layar datar berbagai ukuran. Pasien melakukan terapi dengan duduk nyaman selama perawatan.

Gambar disajikan ke kedua mata melalui cuplikan video saja atau menggunakan permainan video interaktif. Sistem ini bekerja dengan cara memberikan stimulus yang sama ke kedua mata sedangkan bagian dalam layar akan menyajikan rekaman video ke mata ambliopia. Cara lain adalah menggunakan permainan video interaktif. Pasien akan ditampilkan ruang dua dimensi berwarna. Pemain dan latar belakang ditampilkan ke kedua mata, tetapi rintangan, musuh, dan koin hanya ditampilkan ke mata ambliopia. Sehingga untuk dapat memainkan permainan tersebut dengan baik, anak-anak harus memaksa penggunaan mata ambliopia mereka.

Penelitian terbaru menunjukkan bahwa terapi dengan berbasis I-BiT signifikan secara klinis meningkatkan ketajaman penglihatan pada pengukuran minggu ke-6 terapi jika dibandingkan dengan nilai awal baik pada kelompok yang menonton digital video disc (DVD) maupun pada kelompok yang bermain game. Hasil tersebut diukur menggunakan $\log$ MAR berupa deretan huruf untuk menguji ketajaman visual mata.. Hasil tersebut dilihat pada pasien ambliopia tipe strabismik, anisometropik, atau campuran (Herbison et al., 2016).

Penelitian lain mencoba membandingkan efektivitas terapi I-Bit berbasis video game jika dibandingkan dengan oklusi mata menggunakan patch anak usia 5-13 tahun.. Bermain game menggunakan iPad selama 16 minggu dengan durasi 1 jam sehari dibandingkan dengan oklusi mata selama 2 jam sehari keduanya menunjukkan peningkatan ketajaman visual pada minggu ke-16, namun nilai lebih tinggi didapatkan pada kelompok yang melakukan oklusi mata (Holmes et al., 2016).

Pada kelompok usia 4-7 tahun, penggunaan oklusi mata bersamaan dengan bermain video game selama 30 menit per hari menunjukkan hasil peningkatan yang lebih baik dan secara signifikan ketajaman visual yang lebih tinggi dibandingkan dengan kelompok yang hanya melakukan oklusi mata. Hasil ini dilaporkan pada pengukuran minggu ke-6 (Dadeya and Dangda, 2016). Penggunaan oklusi mata dan bermain video game I-Bit juga menunjukkan peningkatan signifikan dan lebih banyak perbaikan dibandingkan dengan hanya menggukan oklusi mata saja (Rajavi et al., 2019)

Berdasarkan hasil-hasil tersebut, terapi I-BiT bisa dipertimbangkan sebagai terapi tambahan pada penderita ambliopia dengan beberapa alasan lainnya. Terapi I-Bit memiliki pemutar DVD internal dan beberapa macam format video game seperti PacMan, Snake, Tetris dan Dig rush yang memungkinkan anak-anak untuk memilih DVD atau pun permainan yang mereka inginkan (Boniquet-Sanchez and Sabater-Cruz, 2021).

Dengan demikian, tingkat kepatuhan anak dapat lebih ditingkatkan sebab anakanak dibiarkan memilih sesuai minat mereka. Beberapa game yang disediakan seperti Dig rush memiliki level permainan yang menyesuaikan dengan kemampuan pengguna (Holmes et al., 2019). Hal ini dapat dilihat pada kuesioner kepuasan pasien menunjukkan bahwa $>90 \%$ peserta merasa menikmati perawatan mereka, $>80 \%$ merasa 
waktu yang diberikan tepat, dan $67 \%$ atau lebih merasa mudah berkonsentrasi. Kepatuhan terhadap setiap perlakuan sangat baik dengan mayoritas peserta bermain game/menonton DVD selama 30 menit pada setiap sesi (Herbison et al., 2016).

Beberapa aplikasi dapat di instal pada sistem operasi windows 7 atau spesifikasi lebih tinggi sehingga dapat dengan mudah di gunakan pada komputer pribadi di rumah . Hal ini memudahkan dalam hal terapi yang dapat diawasi oleh orang tua di rumah, tidak harus diawasi dokter . Berdasarkan durasi, terapi dengan I-BiT memerlukan waktu lebih singkat yakni sekitar 30 menit hingga 1 jam sehari dibandingkan dengan oklusi mata yang membutuhkan waktu 2- 14 jam perhari tergantung usia dan derajat ambliopia.

Kelebihan lain yang membedakan I-BiT dengan terapi konvensional sebelumnya adalah kemampuan membuat mata ambliopia bekerja keras bersama-sama dengan mata yang normal. Tujuan pengobatan tersebut tidak hanya untuk meningkatkan ketajaman visual mata ambliopia tetapi juga mengembalikan fusi binokular dan stereopsis. Stimulasi langsung stereopsis di rumah menggunakan RDS di lingkungan permainan meningkatkan stereoacuity pada subjek yang kekurangan stereo dengan riwayat ambliopia (Portela-Camino et al., 2018). Sehingga kedua mata dapat terkoordinasi dan timbul satu gambaran sebagai gambar tunggal setelah melalui proses fusi. Terapi menggunakan video menerapkan prinsip dichoptic didasarkan pada fakta bahwa tugas visual hanya dapat diselesaikan jika kedua mata bekerja bersama.

\section{Kesimpulan}

Terapi berbasis video pada ambliopia memiliki manfaat bagi penderita ambliopia serta dapat menjadi terapi tambahan untuk meningkatkan ketajaman visual penderita. 


\section{BIBLIOGRAFI}

Blair, K., Cibis, G. and Gulani, A. (2021) Amblyopia. Treasure Island (FL): StatPearls Publishing. Google Scholar

Boniquet-Sanchez, S. and Sabater-Cruz, N. (2021) 'Current management of amblyopia with new technologies for binocular treatment', Vision (Switzerland), 5(2). Google Scholar

Dadeya, S. and Dangda, S. (2016) 'Television Video Games in the Treatment of Amblyopia in Children Aged 4-7 Years', Strabismus, 24(4), pp. 146-152. Google Scholar

Herbison, N. et al. (2013) 'Interactive binocular treatment (I-BiT) for amblyopia: Results of a pilot study of 3D shutter glasses system', Eye (Basingstoke), 27(9), pp. 1077-1083.. Google Scholar

Herbison, N. et al. (2016) 'Randomised controlled trial of video clips and interactive games to improve vision in children with amblyopia using the I-BiT system', British Journal of Ophthalmology, 100(11), pp. 1511-1516. Google Scholar

Holmes, J. M. et al. (2016) 'Effect of a binocular ipad game vs part-time patching in children aged 5 to 12 years with amblyopia a randomized clinical trial', JAMA Ophthalmology, 134(12), pp. 1391-1400. Google Scholar

Holmes, J. M. et al. (2019) 'A Randomized Trial of Binocular Dig Rush Game Treatment for Amblyopia in Children Aged 7 to 12 Years', Ophthalmology, 126(3), pp. 456-466. Google Scholar

Ilyas, S. and Yulianti, S. rahayu (2014) Ilmu Penyakit Mata edisi keempat. 4th edn. jakarta: Balai Penerbit FK UI. Google Scholar

Mocanu, V. and Horhat, R. (2020) 'Prevalence and Risk Factors of Amblyopia among Refractive Errors in an Eastern European Population', pp. 1-11. Google Scholar

Portela-Camino, J. A. et al. (2018) 'A Random Dot Computer Video Game Improves Stereopsis', Optometry and Vision Science, 95(6), pp. 523-535. Google Scholar

Rajavi, Z. et al. (2019) 'Comparison between patching and interactive binocular treatment in amblyopia: A randomized clinical trial', Journal of Current Ophthalmology, 31(4), pp. 426-431. Google Scholar

\section{First publication right: \\ Jurnal Syntax Fusion: Jurnal Nasional Indonesia}

This article is licensed under:

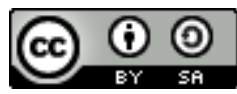

